\title{
Landslide Impact Assessment Using Projection Rainfall Data from Climate Change Scenario
}

\author{
Tingyeh Wu *, Hung-Ju Shih, Hsin-Chi Li, Yuan-Fong Su, and Yung-Ming Chen \\ National Science and Technology Center for Disaster Reduction, New Taipei City, Taiwan, R.O.C.
}

Received 3 July 2015, revised 29 June 2016, accepted 18 July 2016

\begin{abstract}
This study ascertains landslide impact under climate change. The disaster impact under climate change was estimated by calculating the variation in safety factor (FS value). The result shows less landslide impact for the late $21^{\text {st }}$ century (2075 - 2099) than in the late $20^{\text {th }}$ century $(1979$ - 2003). The relationship between rainfall characteristics and landslide susceptibility was then clarified. A total of 40 out of 82 typhoon events from the late $20^{\text {th }}$ century and 40 out of 88 events from the late $21^{\text {st }}$ century were selected for estimating landslide impact. The landslide ratio in each event is calculated to find the variation in landslide occurrence between the late $20^{\text {th }}$ and the late $21^{\text {st }}$ century. The result proved that landslide occurrence is highly dependent on the rainfall characteristics. Landslides occurred earlier during each rainfall event for the late $21^{\text {st }}$ century, which is consistent with rainfall characteristics, e.g., high intensity and short duration, for the late $21^{\text {st }}$ century.
\end{abstract}

Key words: Shallow landslide, Climate change, Scenario simulation, Landslide ratio, Sediment volume

Citation: Wu, T., H. J. Shih, H. C. Li, Y. F. Su, and Y. M. Chen, 2016: Landslide impact assessment using projection rainfall data from climate change scenario. Terr. Atmos. Ocean. Sci., 27, 729-740, doi: 10.3319/TAO.2016.07.18.03

\section{INTRODUCTION}

More sediment disasters have recently been triggered by torrential rainfall events, causing serious disasters in upstream river basins. Some of these disasters occurred on a small scale, but still resulted in serious impacts to the topography and increased the risks to mountain communities. Typhoon Morakot in 2009 brought about $3000 \mathrm{~mm}$ rainfall, causing serious disasters and various impacts to infrastructure, communities and roads on the basin scale. Typhoon Megi in 2011 brought torrential rainfall at $183 \mathrm{~mm} \mathrm{hr}^{-1}$ in northeast Taiwan, causing a serious landslide at National Highway No. 9 (Shang 2010; Executive Yuan 2011). Torrential rain in Hiroshima, Japan in 2014 poured down $183 \mathrm{~mm}$ of rain within two hours. This event triggered shallow landslides and debris flows at hill slopes and seriously damaged houses and the highway. These disasters show that the increasing frequency of torrential rain has brought more serious and sudden sediment disasters in many river basin areas (Sabo Department of MLIT 2014). The Ministry of Science and Technology also set out to determine the impact of future climate change in Taiwan. Compared with

\footnotetext{
* Corresponding author

E-mail: tingyehwu1060@ncdr.nat.gov.tw
}

the average rainfall for the current period (1974 - 2003), rainfall will increase roughly $10-30 \%$ at the end of this century with higher intensity and longer duration (Cheng et al. 2009; Hsu et al. 2011; Water Resource Agency 2013).

Recent studies have shown that future meteorological variation will influence many aspects, not only meteorological aspects, but also increase the risks for disasters. Visser et al. (2014) addressed the probable disaster impacts from meteorological, hydrological, and climatological events. The disaster impact caused by climate change can be shown in terms of impact to wealth and population change, making it is easier to recognize the scale of disaster impact. Impact caused by climate change also includes vulnerability, and it was found that meteoroidal physical phenomena, e.g., rainfall amount and rainfall type, will change and influence the relative disaster impacts.

Climate change also has great influence on water and sediment related issues, e.g., flood, drought, water supply, and water resources (Booij et al. 2006; Boukhris et al. 2008; Wang et al. 2013). Many studies have addressed the disaster impacts in different scenarios or by single events on different scales. The river discharge variation caused by climate change was discussed and analyzed, with water related 
disasters and their protection measurements further discussed. Landslide disaster impact is an important issue in mountain areas and is also related to water resources and ecosystems (Beniston 2003). Hultén et al. (2007) focused on landslide risk under climate change in Sweden, specifically the variation caused by meteorological changes. However, the result was estimated based on the assumption of water level differences. The probable phenomenon is able to be determined under the assumption of water level increase or decrease. To connect landslide activity with climate change projection data, Collison et al. (2000) used Global Circulation Model (GCM) model data combined with a Global Information System (GIS)-based slope hydrology/stability model to estimate the unstable area. The landslide occurrence variation is represented by the long-term trend in landslide area changes. Coe and Godt (2012) established the landslide activity assessment process for climate change and their strengths and weaknesses. Crozier (2010) discussed the appropriate form and resolution of rainfall data for landslide assessment. These studies mentioned the methods, materials, and the estimation of landslide impacts under different climate change scenarios. These studies mainly discussed the trend in landslide impact from the current period to the late $21^{\text {st }}$ century. However, future rainfall becoming more intense and lasting longer periods of time was not considered and estimated. The change in landslide occurrence corresponding to changes in rainfall characteristics will likely become a key factor for future adaptation.

The authors intend to further clarify the connection between landslide impact and projected rainfall data. This study establishes an assessment model and calibrates and verifies it using historical typhoon events. Several simulation stages are performed. The projected hourly rainfall data is then utilized as input data to estimate the landslide impact. Typhoon events in the climate change scenario are also considered to clarify the relationship between landslide occurrence and rainfall variation.

\section{SEDIMENT DISASTERS IN THE GAOPING RIVER BASIN}

This study focuses on a river basin in southern Taiwan, the Gao-Ping River basin (Fig. 1). This river basin consists of three main sub-catchments, which are the Qi-Shan River, Lao-Nong River, and Ai-Liao River sub-catchments. The main flow intersects with the Qi-Shan and Lao-Nong Rivers at Li-Lin Bridge, which is located at the south of Qi-Shan River basin, and intersects with the Ai-Liao River further downstream. Therefore, Li-Lin Bridge serves as the boundary for sediment disaster and flood disaster simulations. The upstream area from the Li-Lin Bridge is used for sediment disaster simulation and the downstream area from Li-Lin Bridge is used for flood simulation.

A longitudinal valley is distributed in the upstream area due to its topographic and geologic conditions. The average gradient is $1 / 142$, so the stream eroded and formed the valley. Many terraces and fans formed along the river path, with communities distributed in these areas. The major lithological formations in this area are Holocene, Pleistocene, Pliocene, Miocene, Eocene, and Mesozoic, which are classified and shown in Fig. 2 (Lee and Fei 2011). The bedrocks were fractured by faults, causing a fragile geological condition in this river basin. The accumulated debris was distributed at the river bank or formed fans along the stream. Due to the topography, communities and roads are constructed along the valley or beside the streams. Only one roadway was built for each of the two main sub-catchments. The community along the roadway can easily become isolated when there is heavy rainfall. Main sediment disasters in this river basin are landslide and debris flow caused by typhoons. Based on annual Soil and Water Conservation Bureau (SWCB) reports (Significant Sediment Disaster Annual Reports, 2006 - 2014) on sediment disasters, a total of 7 events with serious disasters occurred in the Gaoping River basin, in which Typhoon Morakot in 2009 caused the most serious disasters (Table 1).

\section{METHODOLOGY}

This study employs the numerical model TRIGRS (Transient Rainfall Infiltration and Grid-Based Regional Slope-Stability). Landslide susceptibility analysis was carried out using the TRIGRS model to assess slope failure areas and estimate landslide volume using slope failure grid-cells and their corresponding soil depth. The FS values before and after rainfall events were calculated, and a threshold value was defined to classify landslide occurrences. The grid-cell is identified as a landslide grid with whole soil depth while its FS value is below the standard during a rainfall event. The sediment volume caused by landslide was estimated using landslide distribution and soil thickness in each grid-cell.

\subsection{Simulation Scenario}

The rainfall scenario was defined under climate change scenario A1B by the Taiwan Climate Change Projection and Information Platform (TCCIP). Two periods of projected rainfall data during typhoons were analyzed after dynamic global climate model downscaling from the Meteorological Research Institute (MRI-GCM), including the periods of $1979-2003$ (the late $20^{\text {th }}$ century) and $2075-2099$ (the late $21^{\text {st }}$ century). There are a total of 88 typhoon events in the late $20^{\text {th }}$ century and 82 typhoon events projected for the late $21^{\text {st }}$ century.

According to the previous analysis process (Shih et al. 2015), data necessary for sediment disaster assessment include hourly rainfall data and the return period for the selected typhoon event, and the average precipitation for the two periods. Before generating the necessary data, it is important 


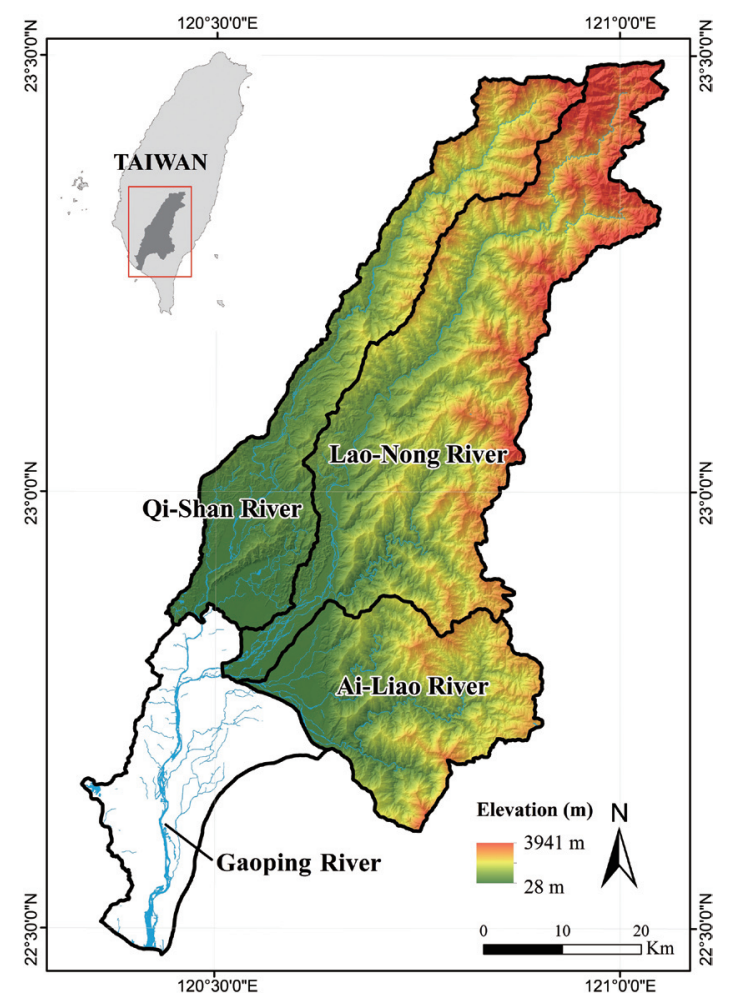

Fig. 1. Elevation map of the Gaoping upstream area.

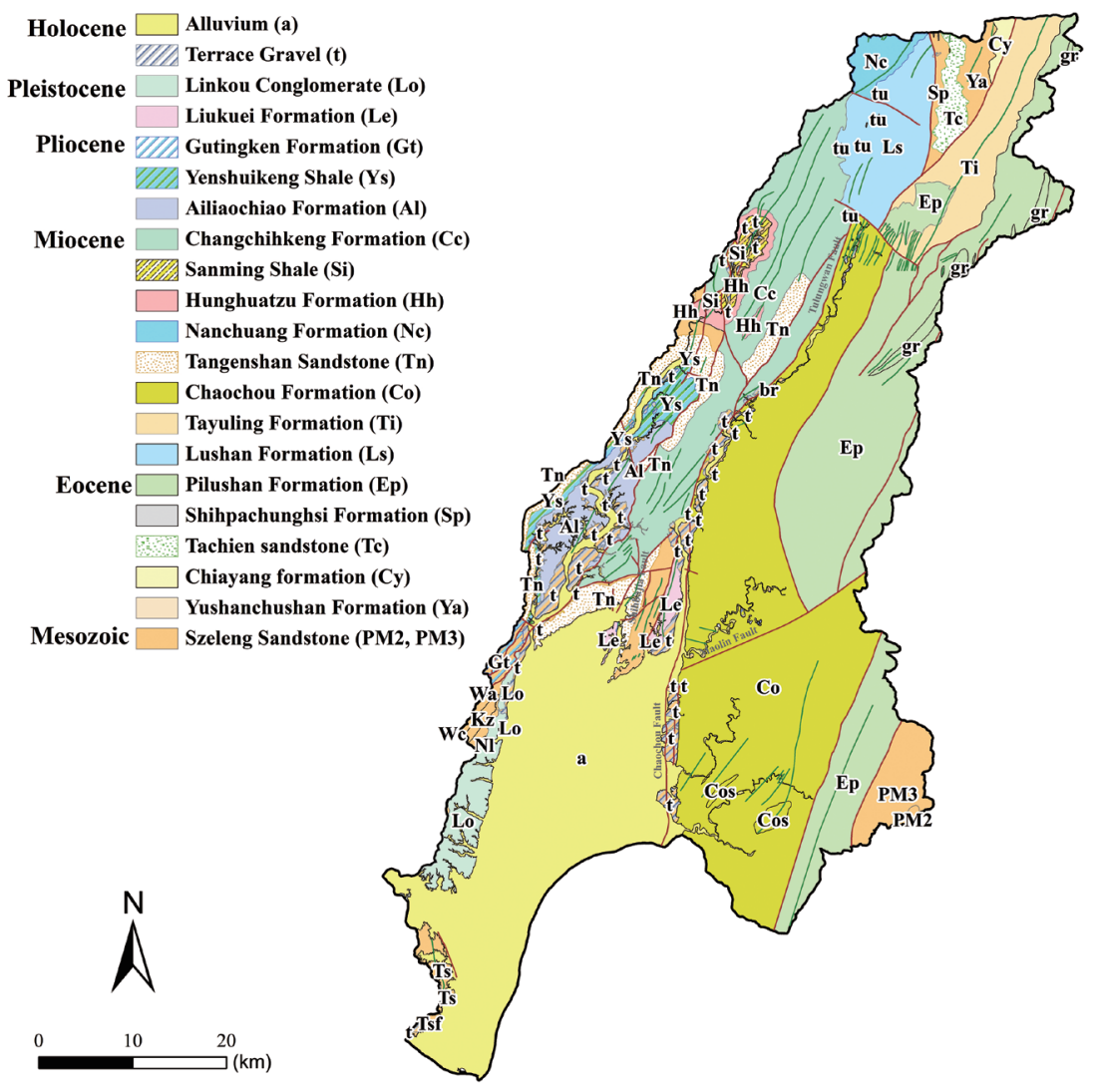

Fig. 2. Geologic map of the Gaoping River basin. 
Table 1. Sediment disasters in the Gaoping River basin between 2006 and 2013.

\begin{tabular}{lccc}
\hline Year & Events & Sediment disasters & Landslide area $\left(\mathbf{m}^{2}\right)$ \\
\hline 2006 & Heavy rainfall & 2 & 42962695 \\
2007 & Typhoon Sepat, heavy rainfall & 3 & 50150096 \\
2008 & Typhoon Kameji & 15 & 26366446 \\
2009 & Typhoon Morakot & 42 & 186747562 \\
2010 & Typhoon Fanapi & 5 & 137911351 \\
2012 & Heavy rainfall & 2 & 104280887 \\
2013 & Typhoon Suri & 1 & 114511813 \\
\hline
\end{tabular}

to establish a standard for determining which typhoon events will be selected from the 82 typhoons events from the late $20^{\text {th }}$ century and the 88 typhoon events projected for the late $21^{\text {st }}$ century. Standards that have been used include 1-, 24-, and 72-hr accumulated rainfall and total rainfall for an event. The standard selected for this study was 24-hr accumulated rainfall. Events were ranked using this standard, which is also used to determine landslide susceptibility in real-time simulations. Furthermore, the sediment disaster impacts of torrential rain can be determined based on this standard.

Two rankings based on 24-hr accumulated rainfall were made for the late $20^{\text {th }}$ century and the late $21^{\text {st }}$ century. The events with highest 24-hr accumulated rainfall were named as Far TOP1 for the late $21^{\text {st }}$ century and Base TOP1 for the late $20^{\text {th }}$ century, and the second highest were named Far TOP2 and Base TOP2, and so on. Accordingly, events in the two rankings were named up to Far TOP88 and Base TOP82. The average hourly rainfall was $66.6-\mathrm{hr}$ for the late $20^{\text {th }}$ century and $58.6-\mathrm{hr}$ for the late $21^{\text {st }}$ century. The average 24-hr accumulated rainfall was $535 \mathrm{~mm}$ for the late $20^{\text {th }}$ century and $917 \mathrm{~mm}$ for the late $21^{\text {st }}$ century (Fig. 3). Observing rainfall characteristics for the two periods, rainfall projected for the late $21^{\text {st }}$ century had higher intensity than the late $20^{\text {th }}$ century rainfall.

Two TOP1 events were selected in the initial simulation, including Base TOP1 and Far TOP1. The total rainfall for Base TOP1 was $1900 \mathrm{~mm}$ and its duration was $134 \mathrm{hr}$, while the total rainfall for Far TOP1 was $1600 \mathrm{~mm}$ and its duration was $80 \mathrm{hr}$ (Fig. 3). The two events had different characteristics, in which Base TOP1 had a long duration and Far TOP1 had higher intensity.

\subsection{TRIGRS Model}

This study utilized the TRIGRS model developed by USGS (the United States Geologic Survey) to analyze the slope land stability in square grid-cell units (Baum et al. 2008). The infiltration using a period of rainfall was considered and its mechanism was extended using the linear solution for the Richard equation (Iverson 2000) and was combined with infinite slope stability analysis to estimate the slope stability [Eq. (1)]. According to the soil and hydrology features in different regions, their geologic and hydrologic parameters were set so that changes in infiltration and the pore water pressure during different times is clarified.

$F S(Z, t)=\frac{\tan \phi^{\prime}}{\tan \delta}+\frac{c^{\prime}-\psi(Z, t) \gamma_{w} \tan \phi^{\prime}}{\gamma_{s} Z \sin \delta \cos \delta}$

where $\phi^{\prime}$ is the soil friction angle; $c^{\prime}$ is effective soil cohesion; $\gamma_{w}$ and $\gamma_{s}$ are unit weight of water and soil; $Z$ is soil thickness; $\delta$ is gradient; $\psi(Z, t)$ is the pore water pressure status of the soil thickness $Z$ under the time $t$.

\subsubsection{Parameters Dataset}

The TRIGRS model requires users to set surface soil conditions to reflect the real situation and thus increase the validity of the simulation result, including slope gradient, soil thickness, soil cohesion, friction angle, soil unit weight, hydraulic conductivity, hydraulic diffusivity, initial infiltration rate, and initial groundwater level. However, detailed distribution of these parameters is difficult to acquire due to the changes in topographic conditions; uncertainty in the field data is also a key factor that should be considered. We used the dataset from the geologic investigation results by the Central Geological Survey, and selected three typhoon events for calibration.

Geologic conditions influence soil distribution and its fragility. We confirmed the 1:50000 geological map produced by the Central Geological Survey (2010) and checked the total of 23 stratums distributed in the upstream subcatchment of the Gaoping river basin. We checked the detailed information of these stratums and classified them by lithology into 12 categories (Table 2), and setup the same parameter dataset for each classification. The parameters were only set for 11 of the categories because terrace deposits are distributed mainly along the river course, and plane areas are steady in TRIGRS simulations. The parameter dataset is set, including effective cohesion, friction angle, unit weight, hydraulic conductivity, hydraulic diffusivity, 

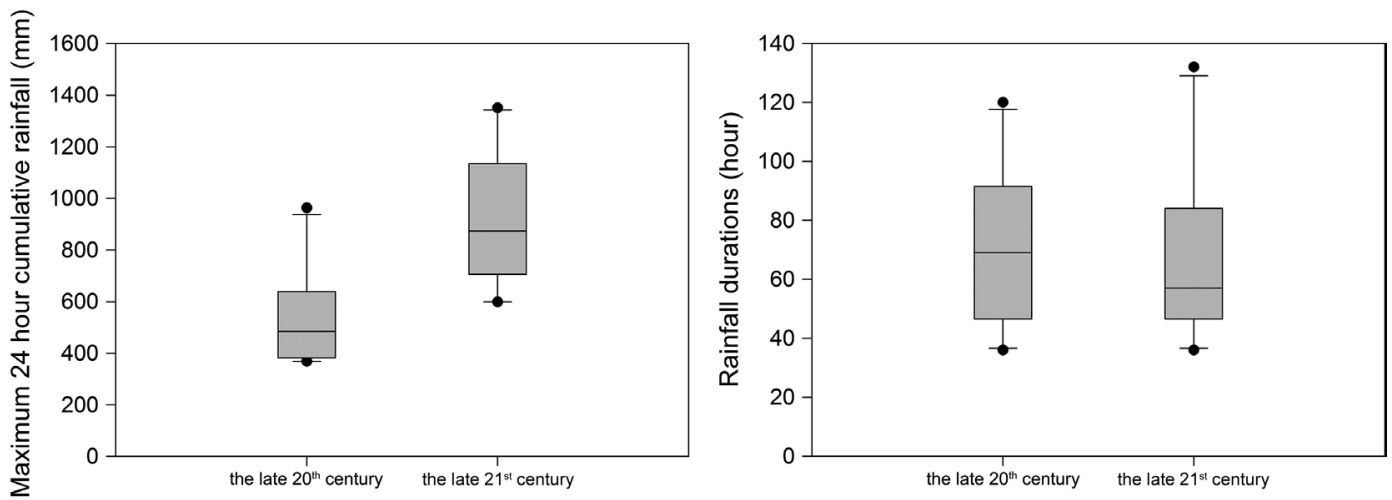

Fig. 3. The average rainfall duration for typhoon events in the late $20^{\text {th }}$ and the late $21^{\text {st }}$ century.

Table 2. Geologic conditions of the study area is used to set the parameters.

\begin{tabular}{rll}
\hline No. & \multicolumn{1}{c}{ Lithology } & \multicolumn{1}{c}{ Stratum } \\
\hline 1 & Igneous rock & Pilushan Fm, Yushan Fm, Shihpachungchi Fm, Chiayang Fm \\
2 & Mainly shale, with thick-bedded siltstone and bedded muddy sandstone & Changchihkeng Fm, Honghuatzu Fm, Sanmin Sh, Nanchunang Fm \\
3 & Schist, Marble & Tananao Schist \\
4 & Slate, Phyllite, Meta Sandstone & Tayuling Fm \\
5 & Conglomerate, Sandstone, Sandy Shale or Mudstone & Liukuei Fm \\
6 & Shale, sandstone and shale interbedded with igneous rock & Chaochow Fm, Lushan Fm, Igneous Rocks \\
7 & Mud with intercalated sandstone & Gutingkeng Fm \\
8 & Gravel, Sand, Clay & Alluvium \\
9 & Alternations of sandstone and shale, intercalated with conglomerate & Tangenshan Ss, Ailioachiao Fm, Wushan Fm, Yenshuikeng Sh \\
10 & Mud, Sand, Gravel & Terrace Deposits \\
11 & Meta-sandstone with slate & Tachien Ss \\
12 & Conglomerate, Mudstone & Lingkou Cg \\
\hline
\end{tabular}

initial water level underground, and initial infiltration.

The other topographic data includes the following:

(1) Digital Terrain Model (DTM) data: The events for calibration and verification are from 2005 - 2010. In order to gain more reliable simulation results, this study employed digital terrain data at a resolution of $40 \mathrm{~m} \times 40 \mathrm{~m}$. This data is from the Aerial Survey Office, Forestry Bureau, Council of Agriculture and produced from aerial photographs from 1980 - 1989. The slope gradient data and flow direction are generated by DTM data.

(2) Landslide inventory: In this study we assumed that the selected typhoon event is the most effective event in the river basin. The landslide caused by that typhoon event can be calibrated using the landslide distribution data for the year of the typhoon event. We collected landslide inventory data from the Forestry Bureau from 2004 - 2013, in which Typhoon Haitong in 2006, Typhoon Sinlaku in 2008, Typhoon Morakot in 2009, and Typhoon Fanapi in 2010 were selected to calibrate the parameters.

(3) Soil thickness and underground water level: These two parameters lack investigation data, so the empirical equation and the assumption were used. Previous studies found that soil thickness is correlated with the slope gradient. We used the data from previous studies and generated soil thickness data for the whole upstream area (NCDR 2012). The groundwater water level is assumed as the same as the soil thickness, which represents that groundwater levels are located at the soil and colluvium interface (Wu 2006; Chen et al. 2011; NCDR 2012).

(4) Hydraulic conductivity and hydraulic diffusivity: Normally the hydraulic colluvium conductivity and weathering layer is between $10^{-4}$ and $10^{-6} \mathrm{~m} \mathrm{~s}^{-1}$. Hydraulic diffusivity is in the $10-400$ range under different environmental conditions. The initial infiltration shows the soil moisture before rainfall. The initial infiltration is 0.01 of hydraulic conductivity if there was $100-500 \mathrm{~mm}$ accumulated rainfall before the simulation. The initial infiltration is $10^{-8} \mathrm{~m} \mathrm{~s}^{-1}$ if no rainfall occurred before the simulation. The main purpose of this study is to analyze rainfall events and landslide occurrence, so we assumed the soil is dry 
and initial infiltration is $10^{-8} \mathrm{~m} \mathrm{~s}^{-1}$ (Chen et al. 2005).

\subsubsection{Calibration Criteria}

In order to calibrate the parameters and increase the model precision we used the error matrix method and modified success rate (MSR) as the criteria for calibration. According to Table 1, typhoon events that had the most and fewest landslide areas were selected for calibration, including Typhoon Haiti in 2005, heavy rainfall in 2006, Typhoon Sepat and heavy rainfall in 2007, Typhoon Kamegi in 2008, Typhoon Morakot in 2009, and all typhoon events in 2011. We also selected a typhoon event for verification. Typhoon Fanapi caused large numbers of landslide areas and a concentrated rainfall occurred with $426.5 \mathrm{~mm}$ in $24 \mathrm{hr}$. The rainfall characteristics of the event included intense rainfall within a short period of time, so the event was selected for verification (Chen and Huang 2014). The landslide inventory from 2004 - 2013 from the Forestry Bureau was utilized to calculate the MSR value (Fig. 4 and Table 3).

We utilized an error matrix to calculate the landslide success rate and non-landslide success rate. Whether or not the parameters are accepted is based on the landslide and non-landslide success rates calculated from the simulation results. However, we found that lower success rates were associated with events that had very few landslides. It is sometimes difficult to identify landslides in the simulation due to sediment movement. Bare land on the map may be the docked place of a landslide instead of its source. We therefore adopted a MSR to confirm if the simulation result is acceptable or not.

The calibration process includes three steps. The study area with simulation results is first separated based on the SWCB sub-catchment map. The average area of each subcatchment is approximately $21.39 \mathrm{~km}^{2}$, and the river basin was divided into a total of 160 areas. Second, the subcatchment map is overlapped with the historical landslide map. Finally, the MSR value is calculated based on the subcatchment scale. We used $70 \%$ as the standard to determine if the model is acceptable or not. If the MSR value of the event is over 70\%, the parameter dataset can be used for the next simulation. If it is not, the parameter dataset should be modified (Chen et al. 2011).

\section{IMPACT ASSESSMENT RESULTS}

\subsection{Landslide Assessment Result of Single and Multi-Events}

Landslide impact assessment was carried out by considering two TOP 1 events in the late $20^{\text {th }}$ century and late $21^{\text {st }}$ century. The shallow landslides distribution was determined based on the simulation results. The simulation process determines the FS value and landslide occurrence was defined as a FS value smaller than 1.0. The result shows that most of the landslide areas caused by both events are in the upstream Lao-Nong and Ai-Liao River areas, but very few landslides occurred upstream of the Qi-Shan River (Fig. 5). The simulation result also shows the two Top1 events have a roughly 20-yr landslide return period for the mountain area. The areas are also places with high landslide frequency and match the distribution of shallow landslides (Fig. 6).

The sediment ratio and sediment volume were estimated and shown in Fig. 7. The landslide ratio for the two events is $5.03 \%$ for Base TOP1 and $0.9 \%$ for Far TOP1. The landslide ratio result indicates that more landslides occurred in the Base TOP1 event. According to Wu et al. (2011), the sediment ratio for far TOP1 is less than the landslide ratio caused by Typhoon Mindulle in 2004 (landslide ratio is 1.3\%) and Typhoon Chong-Mi in 2008 (landslide ratio is 1.4\%). Furthermore, the hourly rainfall for the two events is also shown in Fig. 5. We cited the rainfall duration definition by Chen et al. (2012). A duration of less than 12-hr is defined as short duration, duration between 12- and 24-hr is medium duration, and duration longer than 24-hr is long duration. High intensity rainfall is defined as average intensity over $30 \mathrm{~mm} \mathrm{hr}^{-1}$.

The high intensity rainfall for the far TOP1 event continued for $27 \mathrm{hr}$, but only $11 \mathrm{hr}$ for the Base TOP1 event. The average rainfall intensity for the Far TOP1 event is much higher than that for the Base TOP1 event. However, the simulation result shows that the landslide ratio for the Base TOP1 event is much higher. A probable reason for the large number of landslides that occurred and resulted in high sediment volume is the higher number of instable grid-cells caused by the long rainfall duration. This result also proved that the landslide model is not only influenced by rainfall intensity or total rainfall, but also by rainfall duration, and that rainfall characteristics will affect landslide susceptibility.

The landslide sediment volume was calculated based on landslide area and soil thickness. The sediment volume of Base TOP1 was $612071200 \mathrm{~m}^{3}$ in total, and was $107448000 \mathrm{~m}^{3}$ for Far TOP1. Compared with Typhoon Morakot in 2009, Far TOP1 had far smaller sediment volume and impact levels. When the landslide impact is estimated based on the result of individual events, which are selected according to the ranking standard, the ranking method will affect the landslide impact assessment result. Events from the late $20^{\text {th }}$ and the late $21^{\text {st }}$ century are currently ranked by their 24-hr accumulated rainfall, but this does not necessary mean the most serious events were selected.

It is hard to represent the variation trend using one single event. In order to show the overall variation between the late $20^{\text {th }}$ and the late $21^{\text {st }}$ century, a further assessment was conducted using multiple event simulations.

\subsection{Landslide Assessment Results of Multi-Events Simulations}

The multi-event simulations were carried out by 

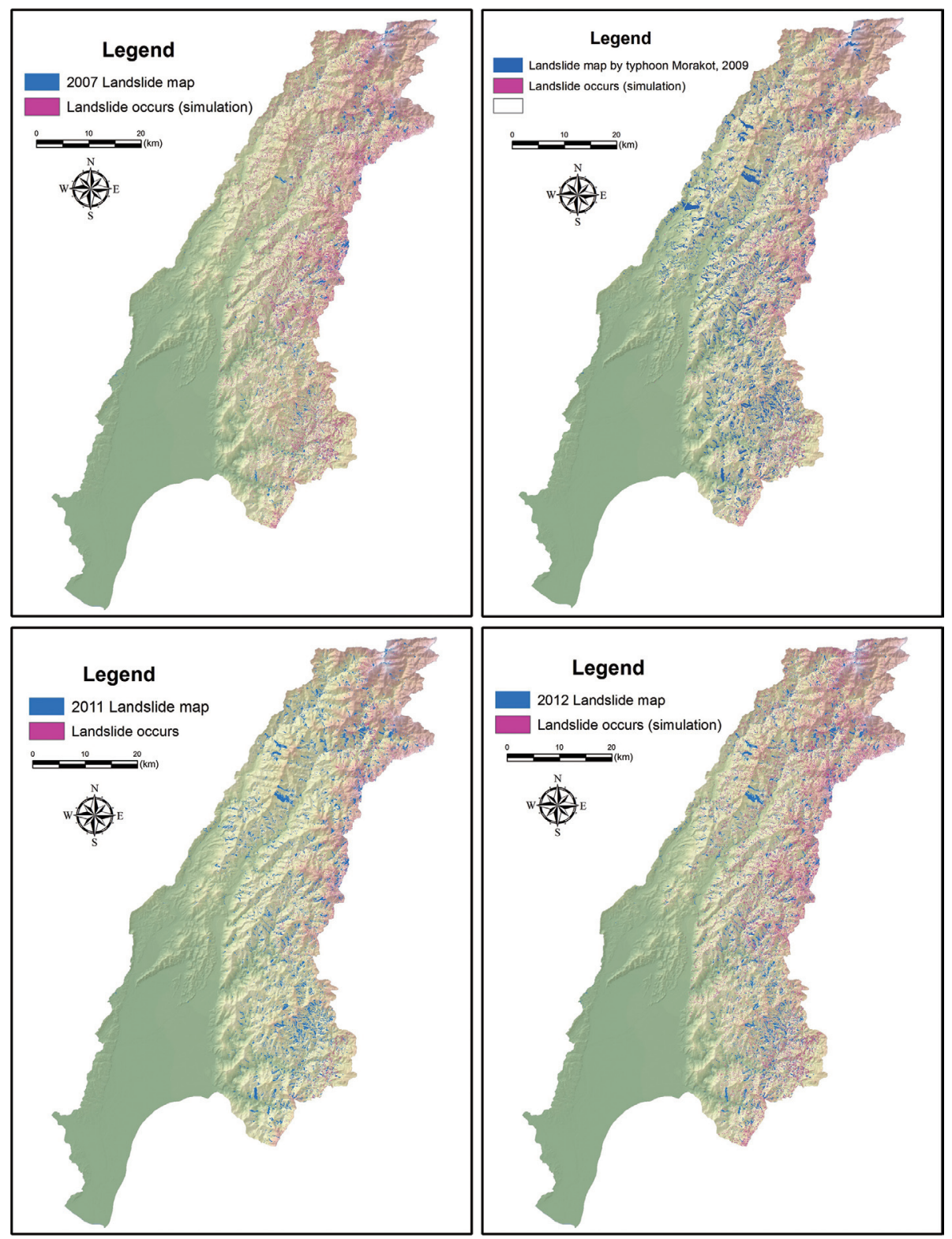

Fig. 4. Landslide calibration and verification.

Table 3. Landslide calibration results.

\begin{tabular}{c|c|ccc|c}
\hline \multicolumn{2}{c|}{ Error matrix } & \multicolumn{3}{|c|}{ Error matrix method } & Modified success rate, MSR \\
\hline & Rainfall events & $\begin{array}{c}\text { Landslide Success } \\
\text { rate (\%) }\end{array}$ & $\begin{array}{c}\text { Non-landslide } \\
\text { success rate (\%) }\end{array}$ & $\begin{array}{c}\text { Total Success rate } \\
(\%)\end{array}$ & MSR (\%) \\
\hline \multirow{5}{*}{ Calibration } & 2005 Typhoon Haiton & $91.36 \%$ & $65.00 \%$ & $88.05 \%$ & $78.18 \%$ \\
& 2006 Heavy rainfall and Typhoon Bilis & $77.20 \%$ & $85.1 \%$ & $78.6 \%$ & $81.15 \%$ \\
& 2008 Typhoon Kameji & $49.21 \%$ & $96.77 \%$ & $58.49 \%$ & $72.99 \%$ \\
& 2009 Typhoon Morakot & $93.91 \%$ & $72.72 \%$ & $92.45 \%$ & $83.32 \%$ \\
\hline Variation & 2011 All typhoon events & $95.1 \%$ & $86.6 \%$ & $94.3 \%$ & $90.85 \%$ \\
\hline
\end{tabular}




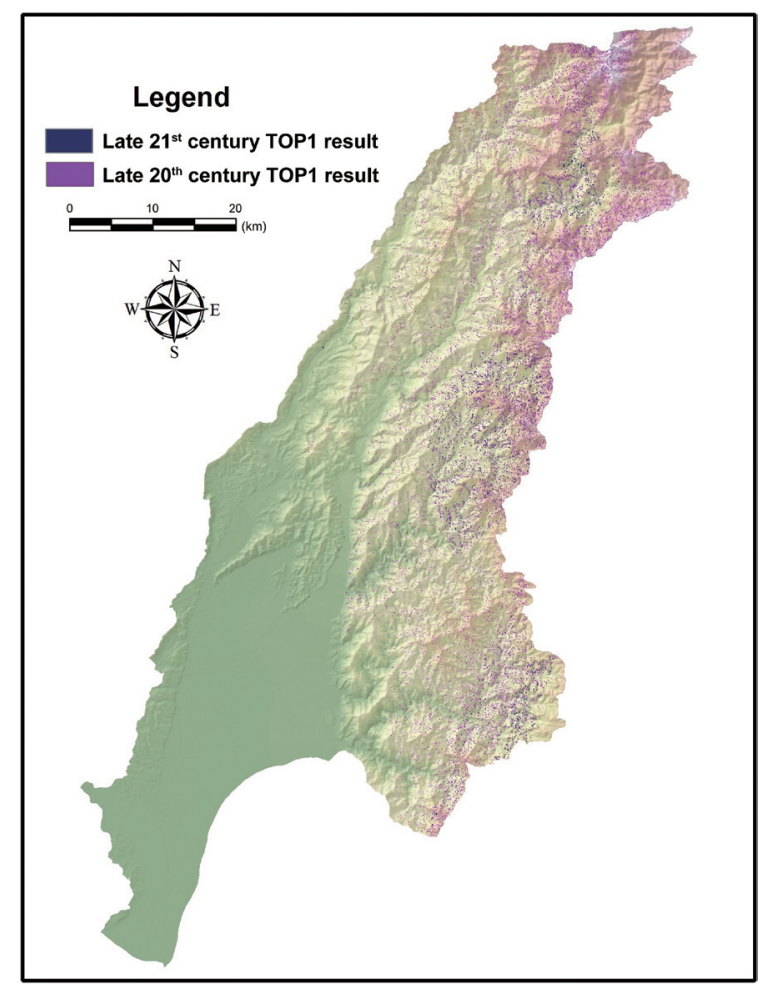

Fig. 5. Landslide simulation results for TOP1 events in the late $20^{\text {th }}$ and the late $21^{\text {st }}$ century.

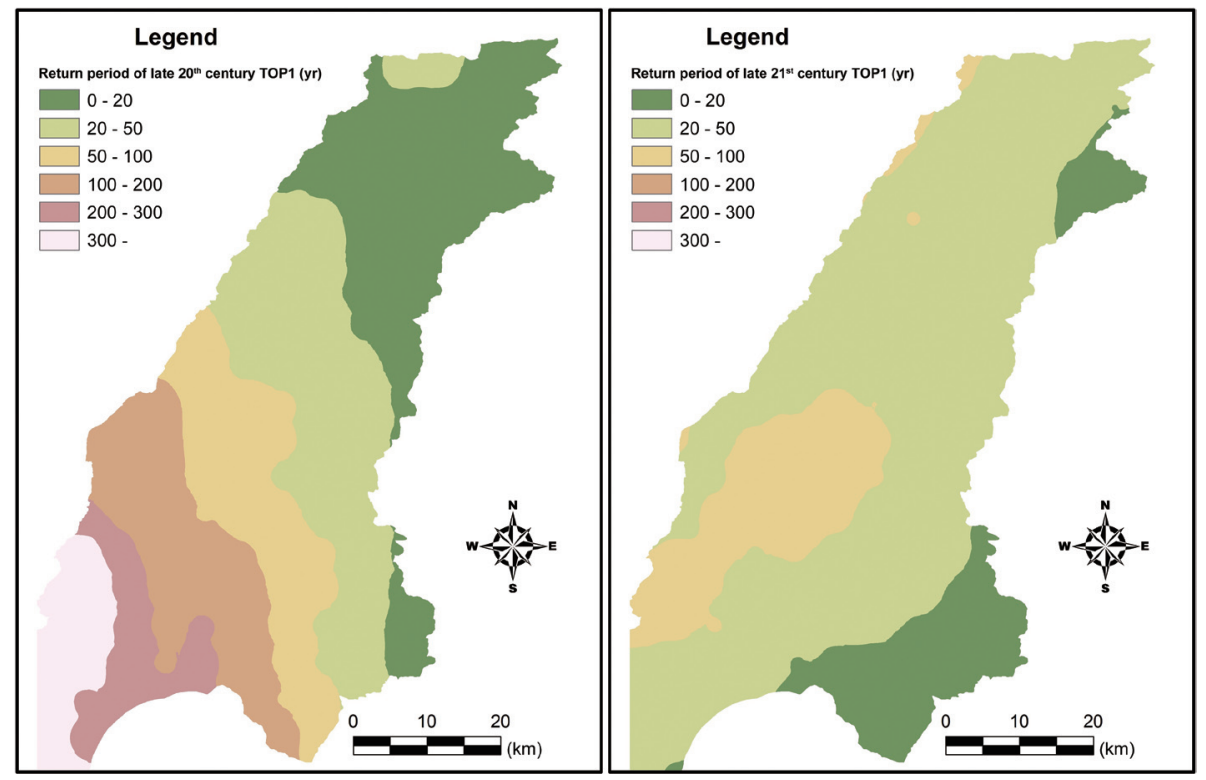

Fig. 6. Return period of two TOP1 events (left: late $20^{\text {th }}$ century TOP1, right: late $21^{\text {st }}$ century TOP1). 


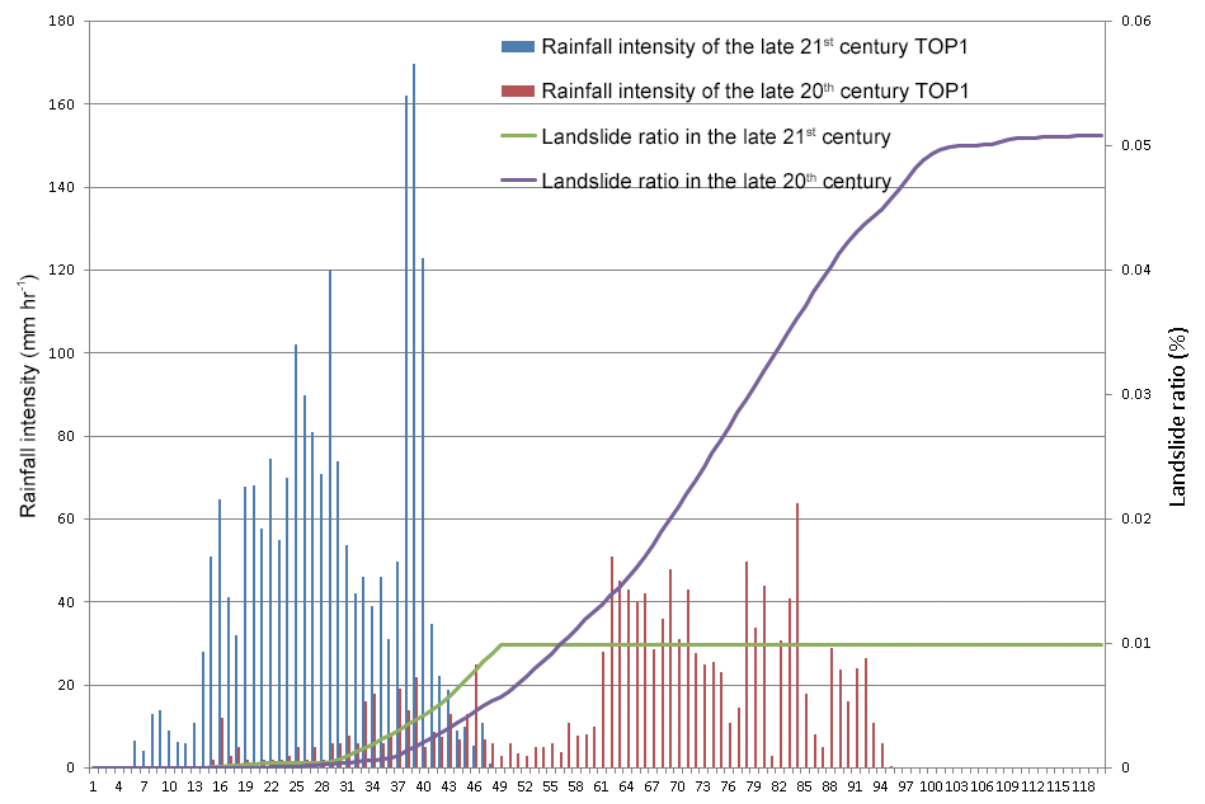

Fig. 7. Landslide simulation results for Base TOP1 and Far TOP1.

selecting 10 events from the two periods (TOP1 to TOP10). Hourly precipitation data from those events is used as the input data for finding sediment volume and maximum landslide ratio, and the landslide occurrence variation between the late $20^{\text {th }}$ and the late $21^{\text {st }}$ century will be displayed.

The results show that sediment volume and landslide ratio exhibit a downward trend from the late $20^{\text {th }}$ and the late $21^{\text {st }}$ century. In Fig. 8 an approximately $5 \%$ landslide ratio will occur during the Base TOP1 events, which is the second most serious event compared with the landslide ratio of 7.3\% during Typhoon Morakot. The difference in average sediment volume between the late $20^{\text {th }}$ and the late $21^{\text {st }}$ century is approximately $5269 \mathrm{~m}^{3}$, and the difference between the average landslide ratio for the two periods is roughly $0.4 \%$. This result shows that there is no significant difference between landslide impacts in the late $20^{\text {th }}$ and the late $21^{\text {st }}$ century. Based on the landslide ratio and landslide sediment volume, landslide impact will slightly decrease in the late $21^{\text {st }}$ century.

The landslide ratios of different events during the late $21^{\text {st }}$ century were further compared (Figs. 8 and 9). The result shows that the TOP6 event in the late $21^{\text {st }}$ century has the largest landslide ratio at $2.99 \%$, and the TOP7 event had the second largest landslide ratio at $2.76 \%$. The two events had a higher landslide ratio than the TOP1 event at only $0.9 \%$. The TOP6 event either has larger total rainfall or 24-hr accumulated rainfall. This shows that the standard we used to select typhoon events can greatly influence the result, and sometimes might lead to a totally different conclusion.

\subsection{Increase in Average Landslide Ratio During the Two Periods}

The previous section explained that rainfall duration can greatly influence landslide susceptibility. To determine how rainfall and landslide susceptibility changes over time, we selected 40 events from each of the late $20^{\text {th }}$ and the late $21^{\text {st }}$ century to a total of 80 events for simulations and compared the rainfall duration in hours. The result shows that the average landslide ratio is 0.8 at the late $21^{\text {st }}$ century and 1.0 during the late $20^{\text {th }}$ century. The standard deviation for the late $20^{\text {th }}$ and the late $21^{\text {st }}$ century is almost the same at 0.01 and 0.008 , respectively (Fig. 10). This result shows that landslide occurrence for the late $21^{\text {st }}$ century is less than that for the late $20^{\text {th }}$ century. The main reason is probably the rainfall duration for those events.

The average landslide ratio is compared for different periods over the rainfall duration in each event. We separated the rainfall duration into four periods, before the $12^{\text {th }}$ hour, from the $12^{\text {th }}$ to $22^{\text {nd }}$ hour, $23^{\text {rd }}$ to $63^{\text {rd }}$ hour, and after the $63^{\text {rd }}$ hour. In the first 12 hours, not many landslides occur, the average landslide ratio approaches 0 . During this period of time the rainfall is extremely low and is not able to trigger a landslide. The average landslide ratio starts to rise from the $12^{\text {th }}$ hour, but only marginally. The average landslide ratio at the late $21^{\text {st }}$ century increases more significantly from the $12^{\text {th }}$ to $23^{\text {rd }}$ hours than during the late $20^{\text {th }}$ century period. However, the difference is not significant at roughly 0.05 . This result shows that a portion of landslides for the late $21^{\text {st }}$ century will occur earlier.

The average landslide ratio at the end of the $21^{\text {st }}$ century rises rapidly from the $23^{\text {rd }}$ to $63^{\text {rd }}$ hours and then the rising speed starts to decrease. For the late $20^{\text {th }}$ century, the average landslide ratio rises at almost the same speed from the $36^{\text {th }}$ hour to $100^{\text {th }}$ hour. Comparing the two curves, it is 
apparent that the landslide area rises rapidly for the late $21^{\text {st }}$ century. In contrast, the landslide area increases steadily in the late $20^{\text {th }}$ century. The average landslide ratio reaches the same value at the $63^{\text {rd }}$ hour for the two periods, meaning that the average landslide area is the same for the two periods.

The curves change more significantly after the $63^{\text {rd }}$ hour, when the average landslide ratio for the late $20^{\text {th }}$ century surpasses the late $21^{\text {st }}$ century. The final difference between the average landslide ratios for the two periods is about 0.2 . This means that there are more landslide areas in the late $20^{\text {th }}$ century and the average landslide ratio almost reaches 1.0. Therefore, this figure shows that landslide oc- currence will increase between the $23^{\text {rd }}$ and $63^{\text {rd }}$ hour for events in the late $21^{\text {st }}$ century. However, for events in the late $20^{\text {th }}$ century, most of the landslides occur after the $63^{\text {rd }}$ hour. This result proves that different rainfall characteristics resulting from climate change will influence landslide occurrence, including occurrence time and the amount. It also shows the preparation time for landslides in the late $21^{\text {st }}$ century will be shorter compared with the late $20^{\text {th }}$ century.

These results show the physical meaning of landslide occurrence, and also the limitations and characteristics of the numerical model. The TRIGRS model sensitivity analysis shows the simulation result will be influenced by several

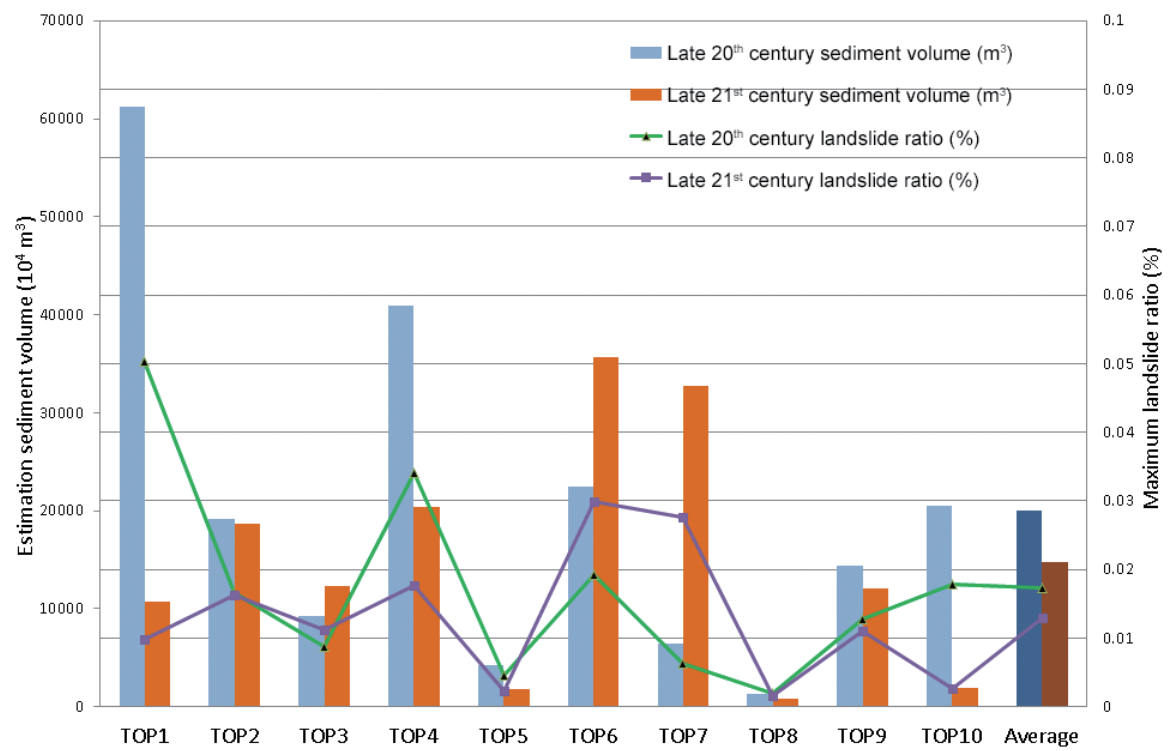

Fig. 8. Simulation results for multiple events.

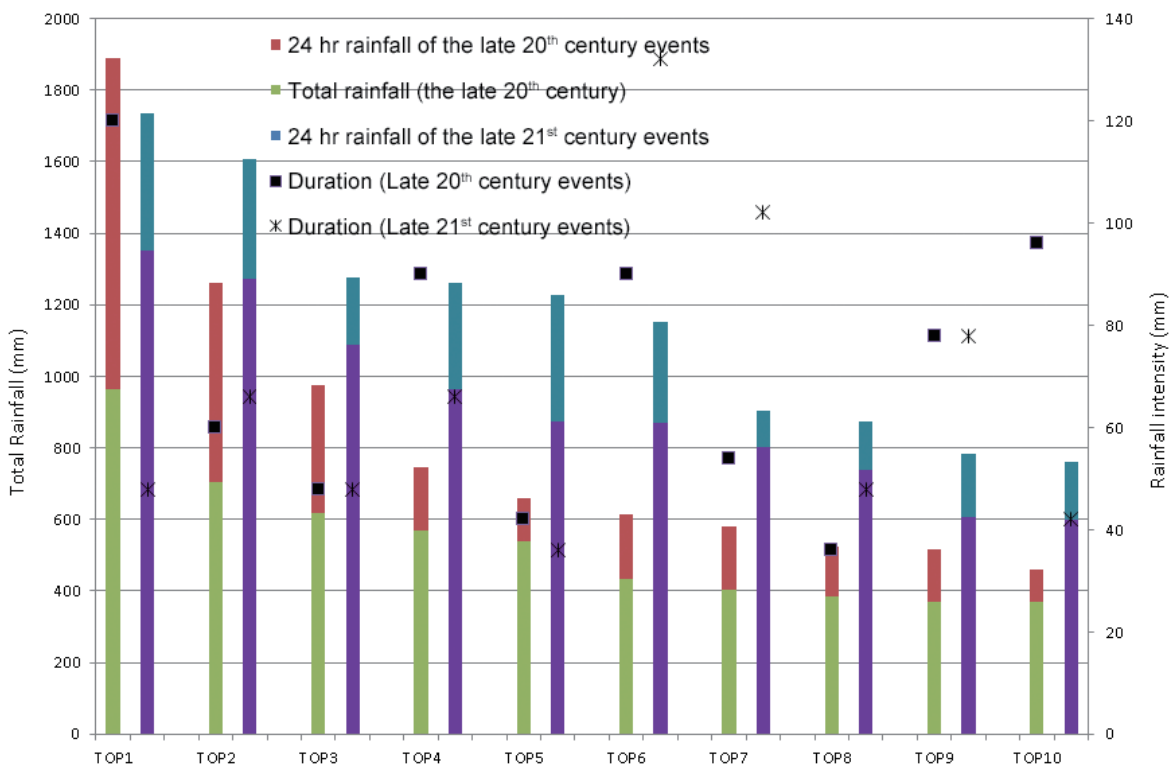

Fig. 9. $24 \mathrm{hr}$ accumulated rainfall and total rainfall for the 10 TOP events. 


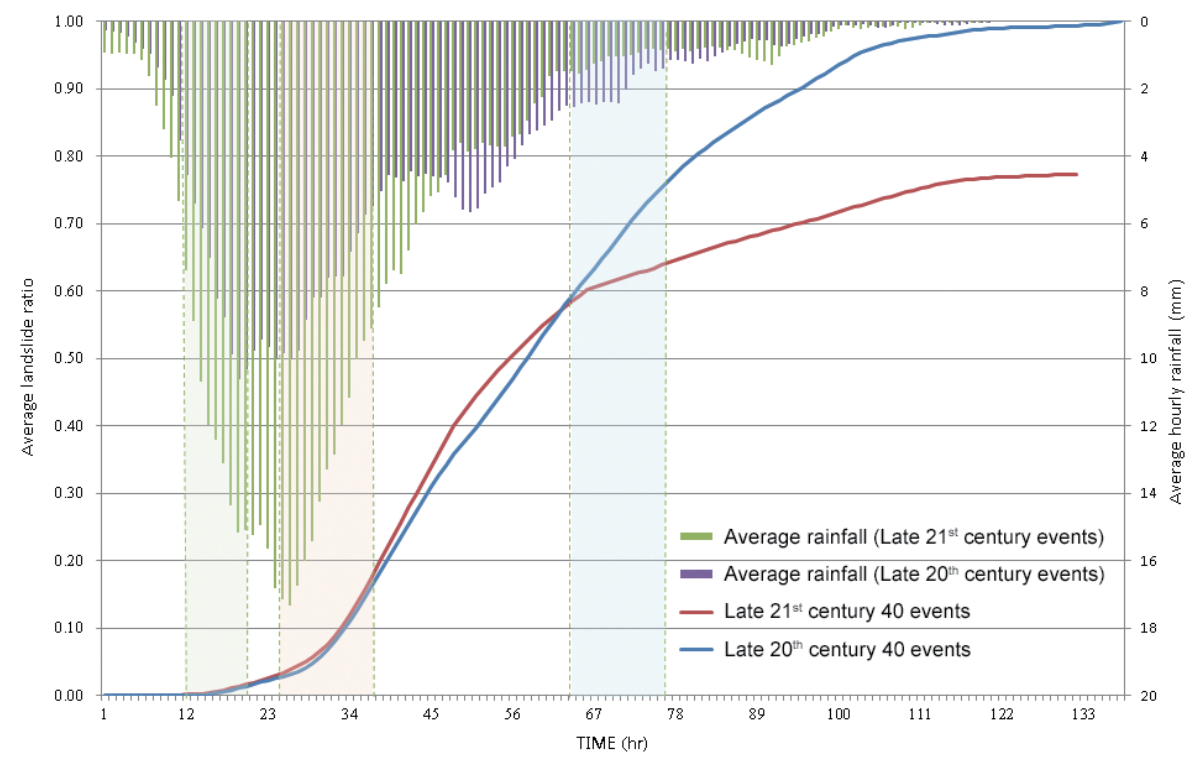

Fig. 10. The average landslide ratio variation in the late $20^{\text {th }}$ century (Base events) and the late $21^{\text {st }}$ century (Far events).

factors, including rainfall duration, rainfall type, accumulated rainfall, and rainfall intensity. Rainfall duration had the greatest effect on the result; that is longer duration causes higher landslide ratio. We also recommend that future studies include all typhoon events into the simulation for disaster impact assessment, including 88 events from the late $20^{\text {th }}$ century and 82 events for the late $21^{\text {st }}$ century. The increase in number of simulation events can effectively decrease the rainfall characteristics error margin, e.g., rainfall duration and rainfall type, but also help determine the landslide impact under climate change.

\section{SUMMARY AND CONCLUSIONS}

This study conducted a landslide disaster impact assessment for the upstream sub-catchment of the Gaoping River basin under a climate change scenario. The assessment model for landslide and debris flow was established and calibrated using historical events. In the analysis process, the landslide assessment model was calibrated using five typhoon events and verified using Typhoon Fanapi in 2010. The results show that the model in this study is capable of estimating landslide distribution for the projected rainfall data.

The TOP1 events for the late $20^{\text {th }}$ and the late $21^{\text {st }}$ century were defined based on 24-hr accumulated rainfall. The simulation result shows that the TOP1 event from the late $20^{\text {th }}$ century caused higher disaster impact than the TOP1 event for the late $21^{\text {st }}$ century. This is most likely caused by the rainfall duration in the typhoon events. In order to clarify if rainfall duration affects disaster impact, we selected a total of 80 typhoon events from the late $20^{\text {th }}$ and the late $21^{\text {st }}$ century for landslide simulations. The result was shown in terms of average landslide ratio and average rainfall intensity. The landslide ratio proved that rainfall duration is the key to landslide occurrence. Landslide occurrence for the late $21^{\text {st }}$ century is lower than the late $20^{\text {th }}$ century; however, landslides occurred earlier during each event for the late $21^{\text {st }}$ century. This study found that landslide occurrence is affected by changes in rainfall characteristics resulting from climate change.

Acknowledgements The authors sincerely thank the Editors and Reviewers for their patience and constructive feedback. The authors are also grateful to Dr. Akio Kitoh of the Japan Meteorological Research Institute for providing MRI data. This project was funded by the Taiwan National Science Council (MOST 102-2621-M-492-001, MOST 1032621-M-865-001, and MOST 104-2621-M-865-001).

\section{REFERENCES}

Baum, R. L., W. Z. Savage, and J. W. Godt, 2008: TRIGRS - A Fortran program for transient rainfall infiltration and grid-based regional slope-stability analysis, version 2.0. Open-File Report 2008-1159, U.S. Department of the Interior, U.S. Geological Survey, 75 pp.

Beniston, M., 2003: Climatic change in mountain regions: A review of possible impacts. Clim. Change, 59, 5-31, doi: 10.1023/A:1024458411589. [Link]

Booij, M. J., M. Huisjes, and A. Y. Hoekstra, 2006: Uncertainty in climate change impacts on low flows. In: Demuth, S., A. Gustard, E. Planos, F. Scatena, and E. Servat (Eds.), Climate Variability and Change-Hydrological Impacts (Proceedings of the Fifth FRIEND World Conference, IAHS Publication (308), IAHS 
Press, 401-406.

Boukhris, O. F., P. Willems, and W. Vanneuville, 2008: The impact of climate change on the hydrology in highly urbanized Belgian areas. Water \& Urban Development Paradigms, CRC Press, Taylor \& Francis Group, 271-276.

Central Geological Survey, 2010: Research on Application of the Investigation Results for the Upstream Watershed of Flood-Prone Area (2/3), Central Geological Survey Report. (in Chinese)

Chen, C. Y., T. C. Chen, F. C. Yu, and S. C. Lin, 2005: Analysis of time-varying rainfall infiltration induced landslide. Environ. Geol., 48, 466-479, doi: 10.1007/ s00254-005-1289-z. [Link]

Chen, D. S. and K. L. Huang, 2014: Report on Typhoons in 2010, Central Weather Bureau, 52-67. (in Chinese)

Chen, S. C., Y. H. Chu, and C. H. Wu, 2012: The long term rainfall trend and landslide distribution in Chishan river watershed. J. Chinese Soil Water Conserv., 43, 293-301.

Chen, T. Y., Z. Y. Feng, and Y. C. Chuang, 2011: An application of TRIGRS on slope failure probability analyses - A case study of Aowanda. J. Chinese Soil Water Conservat., 42, 228-239.

Cheng, K. S., J. C. Hou, Y. C. Wu, and J. J. Liou, 2009: Assessing the impact of climate change on annual typhoon rainfall-A stochastic simulation approach. Paddy Water Environ ., 7, 333-340, doi: 10.1007/s10333-0090183-9. [Link]

Coe, J. A. and J. W. Godt, 2012: Review of approaches for assessing the impact of climate change on landslide hazards. In: Eberhardt, E., C. Froese, K. Turner, and S. Leroueil (Eds.), Landslides and Engineered Slopes, Protecting Society Through Improved Understanding, CRC Press, Taylor \& Francis Group, London, 371-377.

Collison, A., S. Wade, J. Griffiths, and M. Dehn, 2000: Modelling the impact of predicted climate change on landslide frequency and magnitude in SE England. Eng. Geol., 55, 205-218, doi: 10.1016/S00137952(99)00121-0. [Link]

Crozier,M.J.,2010: Deciphering the effect of climate change on landslide activity: A review. Geomorphology, 124, 260-267, doi: 10.1016/j.geomorph.2010.04.009. [Link]

Executive Yuan, 2011: Disaster Management White Paper, Executive Yuan.

Hsu, H. H., C. Chou, Y. Wu, M. M. Lu, C. T. Chen, and Y. M. Chen, 2011: Climate Change in Taiwan: Scientific Report 2011 (Summary), National Science Council, Taipei, Taiwan, ROC, 67 pp.
Hultén, C., Y. Andersson-Sköld, E. Ottosson, T. Edstam, and Å. Johansson, 2007: Case studies of landslide risk due to climate change in Sweden. In: Mathie, E., R. McInnes, H. Fairbank, and J. Jakeways (Eds.), Landslides and Climate Change: Challenges and Solutions, Taylor \& Francis Group, London, UK, 149-157, doi: 10.1201/NOE0415443180.ch19. [Link]

Iverson, R. M., 2000: Landslide triggering by rain infiltration. Water Resour. Res., 36, 1897-1910, doi: 10.1029/2000WR900090. [Link]

Lee, C. T. and L. Y. Fei, 2011: Analysis on landslide and debris flow disasters of Gaoping river basin. Professional Engineer Journal, 58, 30-45. (in Chinese)

National Science and Technology Center for Disaster Reduction (NCDR), 2012: 2012 Sediment disaster impact assessment for slope-land area. Technology Report (No. NCDR100-T36), National Science and Technology Center for Disaster Reduction.

Sabo Department of MLIT, 2014: An Outline of a Torrential Rain-Caused Sediment Disaster in Hiroshima Prefecture in August 2014 and Subsequent Response, Ministry of Land, Infrastructure, Transport and Tourism (MLIT). Available at http://www.mlit.go.jp/river/sabo/ H26_hiroshima/141031_hiroshimadosekiryu.pdf.

Shang, J. C., 2010: Report on Typhoon MEGI (1013) of 2010, Central Weather Bureau. (in Chinese).

Shih, H. J., T. Y. Wu, Y. F. Su, C. H. Liu, H. C. Li, Y. M. Chen, and C. H. Chang, 2015: Shallow landslide disaster impact assessment under extreme rainfall event in the climate change scenario. J. Eng. Environ., 34, 7796, doi: 10.6562/JEE.2015.34.5. (in Chinese) [Link]

Visser, H., A. C. Petersen, and W. Ligtvoet, 2014: On the relation between weather-related disaster impacts, vulnerability and climate change. Clim. Change, 125, 461-477, doi: 10.1007/s10584-014-1179-z. [Link]

Wang, J., J. Huang, and T. Yan, 2013: Impacts of climate change on water and agricultural production in Ten Large river basins in China. J. Integr. Agr., 12, $1267-$ 1278, doi: 10.1016/S2095-3119(13)60421-9. [Link]

Water Resource Agency, 2013: Assessment of Hydrologic Scenarios Under Climate Change (2/2), Water Resource Agency, Taipei, Taiwan, R.O.C.

Wu, C. C., 2006: Preliminary study of rainfall-induce landslide susceptibility analysis. Master Thesis, National Chi Nan University, Taiwan, R.O.C.

Wu, C. H., S. C. Chen, and H. T. Chou, 2011: Geomorphologic characteristics of catastrophic landslides during typhoon Morakot in the Kaoping Watershed, Taiwan. Eng. Geol., 123, 13-21, doi: 10.1016/j. enggeo.2011.04.018. [Link] 